\title{
Prioritizing the Effective Urban Space Qualities in Providing Investors Expectations, Using Delphi Technique (Case study: Central District of Mashhad City)
}

\section{ART ICLE INF O}

\section{Article Type}

Original Research

\section{Authors}

Sarvari H.* $P h D$
How to cite this article

Sarvari H. Prioritizing the Effective Urban Space Qualities in Pro-

viding Investors Expectations, Using Delphi Technique (Case study: Central District of Mashhad City). Geographical Researches Quarterly Journal.2019;34(1):21 $-27$.

\begin{abstract}
A B S T R A C T
Aims \& Backgrounds Economic competition among cities has led urban management to seek to attract private sector investment. But, investors are looking for economic justification for investment, and urban space qualities are important to them. Urban designers have different justifications for their economic impact in the process of providing qualities of urban space. The absence of categorized classifications of urban space qualities, based on its impact on economic metrics to direct urban space design methods, has created a challenge to attract investors' attention. The aim of this study was to prioritize the quality of urban space effective in meeting investors' expectations based on the views of urban planners. Methodology To conduct this research, 12 effective qualities in urban space design were selected and the studies were investigated. Then, using Delphi technique, the degree of importance of urban space quality were calculated.

Findings The findings represent a different score for different qualities. Being clean, green, and pleasant were placed in low quality and other qualities and other qualities were placed in the desired classification. Conclusion The first-class qualities offer the highest expectations of the investors in the short-term, midterm and long-term periods.
\end{abstract}

Keywords Urban designers; Design qualities; Investors' expectations
*Department of Urban Planning, Mashhad Branch, Islamic Azad University, Mashhad, Iran

\section{*Correspondence}

Address: Islamic Azad University, Ostad Yousefi Boulevard, Mashhad, Khorasan Razavi Province, IranPhone: +98 (51) 36046970 Fax: +98 (51) 36046970 sarvari_hadi@mshdiau.ac.ir

\section{Article History}

Received: September 17, 2018

Accepted: January 20, 2019

ePublished: February 05, 2019

\section{CIT A T I O N L I N KS}

[Carmona M, et al.; 2002] Stakeholder views on value and urban design, Urban ...; [Carmona M \& Sieh L; 2004] Measuring quality in planning -Managing the performance ...; [Carmona M \& De Magalhaes C; 2006] Innovations in the management of public space ...; [Carmona M, et al.; 2008] Public space the management dimension ...; [Carmona M \& Teasdale S; 2015] Urban design reader ...; [Carmona M; 2017] The formal and informal tools of ...; [Carr S, et al.; 1992] Public Space, Cambridge ...; [Clemente 0 \& Ewing R; 2005] Measuring urban design qualities an illustrated ...; [Golkar K; 2000] Urban design qualities ...; [Madanipour A; 1997] Ambiguities of urban design ...; [Nase L, et al.; 2015] Urban design quality and real state ...; [Rowley A; 1998] Private-property decision makers ...; [Sadeghi S \& Sobhkhiz Zenori Sh; 2015] The effective factors on private sector cooperation as an approach to finance sustainable recourses ...; [Sheppard M; 2015] Essentials of urban design...; [Strenberg E; 2000] An integrative theory of urban ...; [Syms P; 2002] Land, Development and Design ...; [Tibbalds F; 1992] Making people-friendly towns ... 
اقتصادى آنها تامين شده و توجيهات اقتصادى لازم براى

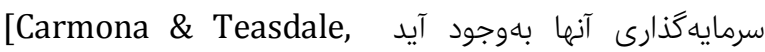
[2015; Madanipour, 1997. به عبارت ديكر سرمايهذاران درخصوص شكل و عملكرد فضاى شهرى و ساير كيفيتهاى آن

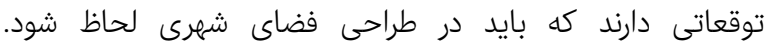

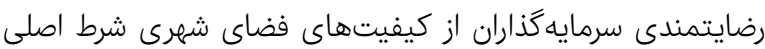

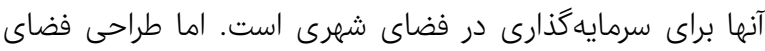

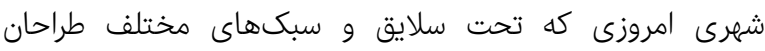

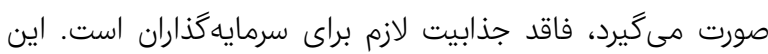

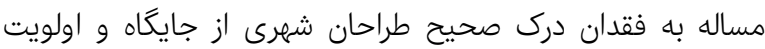

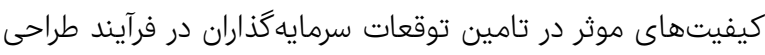

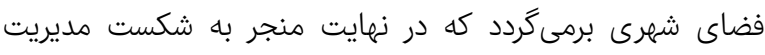

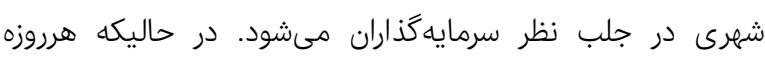
مديران شهرى بر همكارى بيشتر با سرمايهذاران اندان تاكيد مى كنيند

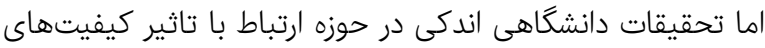

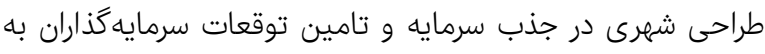

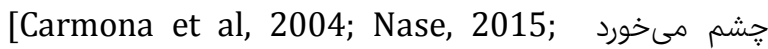
Madanipour, 1997; Rowley, 1998]

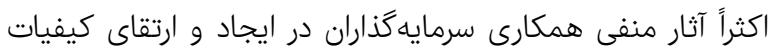

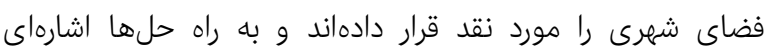

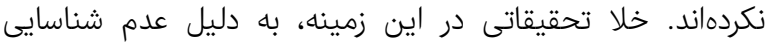
ارتباط ميان كيفيتهاى فضاى شهرى و توقعات سرمايهذانداران

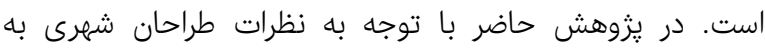

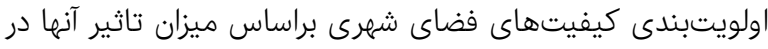

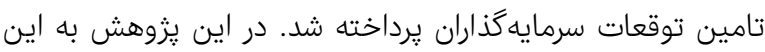

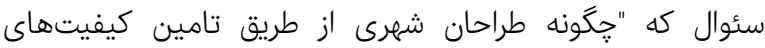

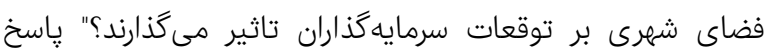

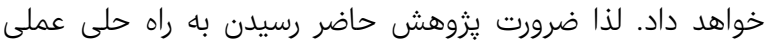

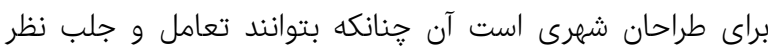
بيشتر سرمايهذاران را در جهت است سرمايهذارى دران در شهر و فضان

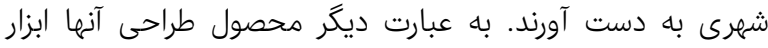
مناسبى براى مديريت شهرى در جلب نظر سرمايهذاراران باشد.

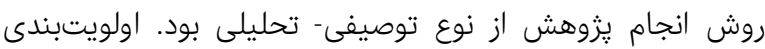

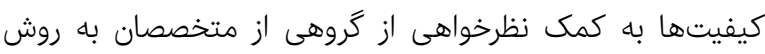

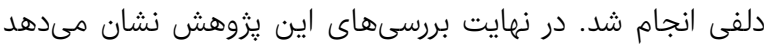

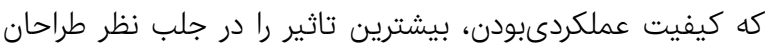

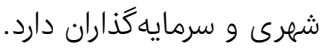
كيفيتهاى فضاى شهرى مرورى بر نظريات ارايهشه يُشيرامون كيفيتهاى فضاى شهرى،

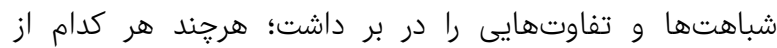
ماحبنظران بر كيفيتهاى خاصى از فضاى داى شهرى تران تمركز

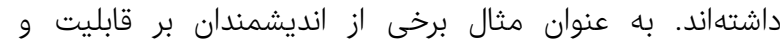
دسترسى همه مردم در جهت انجام تعاملات اجتماعى و ور رخداد

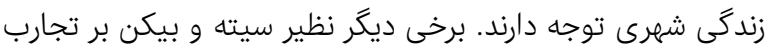

الويتبندى كيفيتهاى فضاى شهرى موثر درى دراى

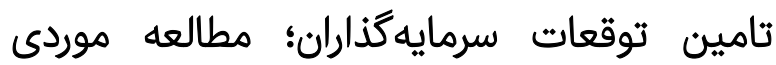

بافت مركزى شهر مشهد

PhD هادى سرورى

كروه شهرسازى، واحد مشهد، دانشَاه آزاد اسلامى، مشهد، ايران

جكيده

اهداف و زمينهها: رقابت اقتصادى ميان شهرها باعث شده است كه مديريت

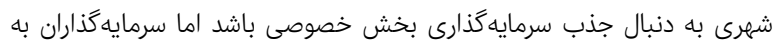

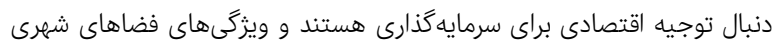

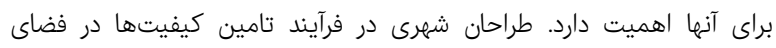

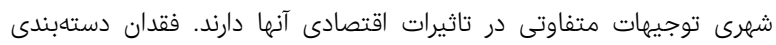

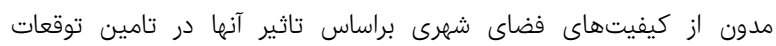

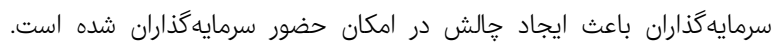

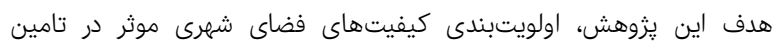

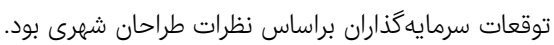

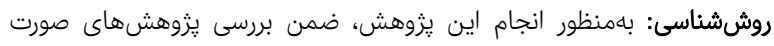

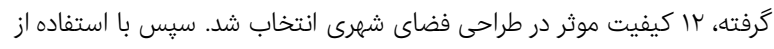

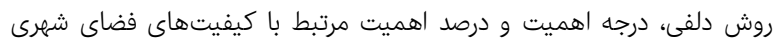

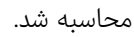

يافتهها: يافتهای ماسل حاصل بيانكر امتياز متفاوت كيفيتهاى مختلف است.

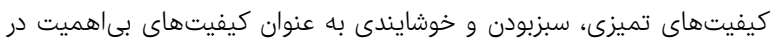

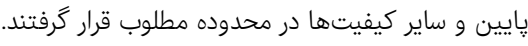

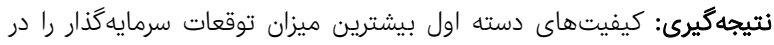

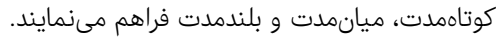

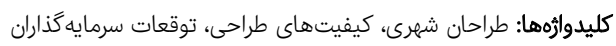

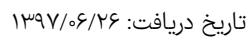

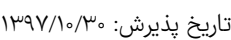
'نويسنده مسئول: sarvari_hadi@mshdiau.ac.ir

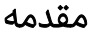

در دوران معاصر، شهرهاى ايران با تعداد اندك و نامطلوب

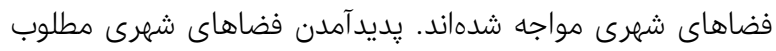

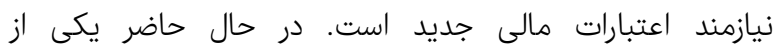

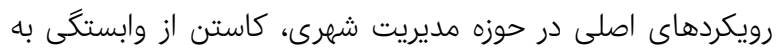

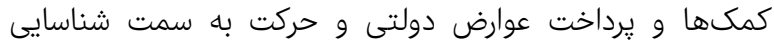

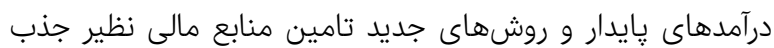

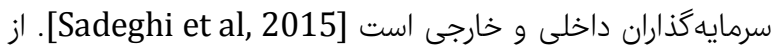
اين رو همكارى مديريت شهرى و طراحان شهرى بارئ سرمايهذاراران

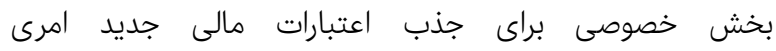
اجتنابنايذير است. در حال حاضر مباحث معاصر بيرابيرامون فضاى شهرى نيز همجون مديريت فضاى شهرى يا بازاريابى فضاى شهرى شيرى

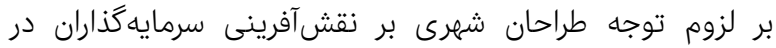
فضاى شهرى و تامين توقعات آنها تاكيد دارد. اما سرمايهذَّاراران در قبال سرمايهذارى در فضاى شهرى توقع دارند تا منافع 


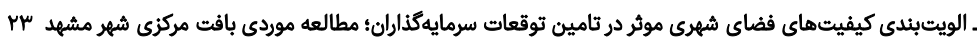

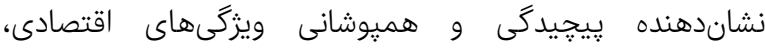

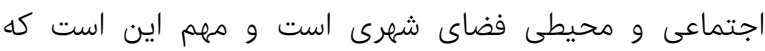

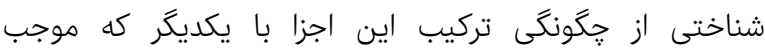
بهينهشدن كيفيتهاى فضاى شهرى مىشود، داشته باشيم. البته

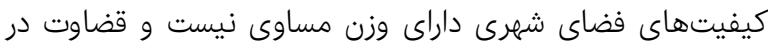

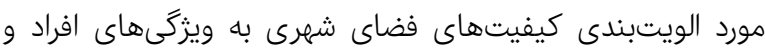

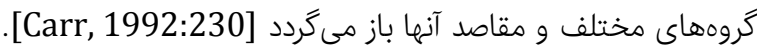

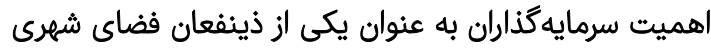

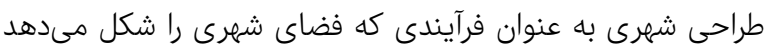
و مديريت مىكند، ناگزير انعكاسدهنده ارزشها و توقعات كسانى

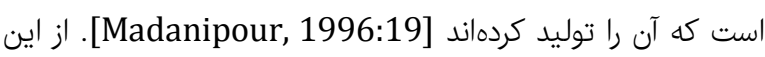

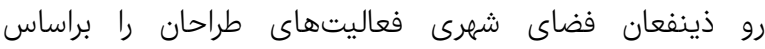
كيفيتهاى فضاى شهرى از طريق آنجه مىبينند و آنجه كه تجريه

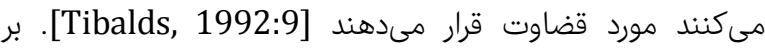

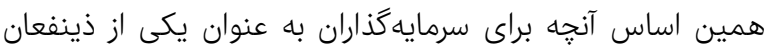

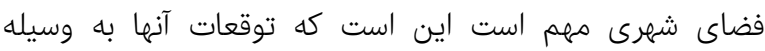
كيفيتهاى فضاى شهرى تامين شده باشد. طراحان شهرى بهر باس

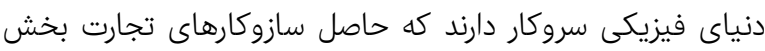

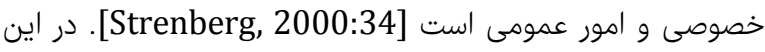
ميان، سازوكارهاى تجارت بخش خصوص خصوصى از اهميت بيشترى إنى

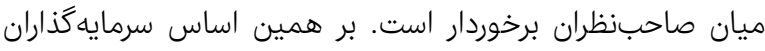

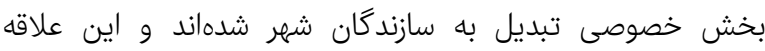

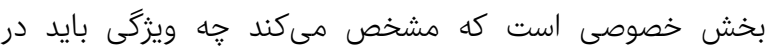

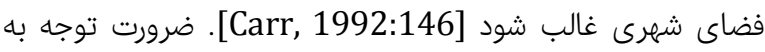
حفظ و مديريت كيفيتهاى فضاى شهرى در طول حيات آن، نياز

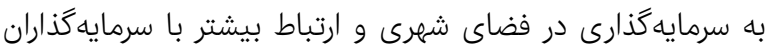

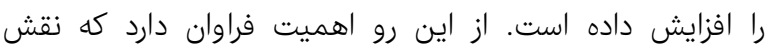
سرمايه گذاران به واسطه حضور در فضاى شهرى مورد نظر طراحان

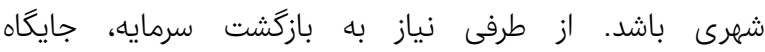
سرمايهگذاران را در كنار مديران و طراحان شهرى شئان قرار داده است.

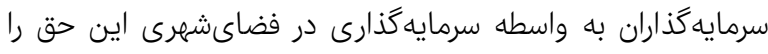

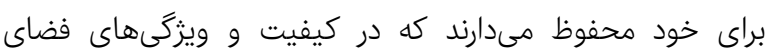

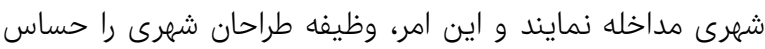

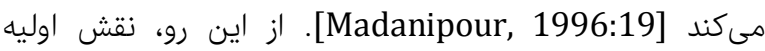
طراحان شهرى زّاسخدادن به الزامات اقتصادى از طريق بيان مجدد

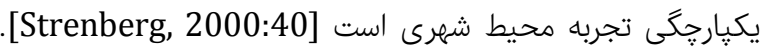

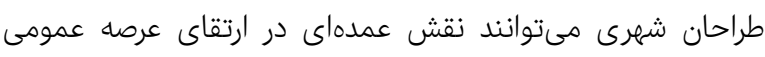

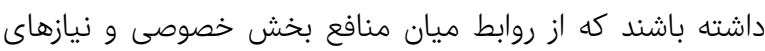

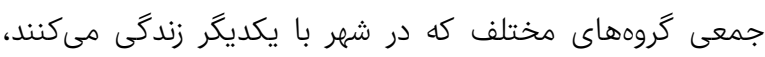
حمايت مىكند. اما بايد توجه داشت كه تاكيد بر تامين توقعات

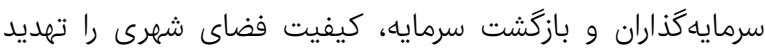

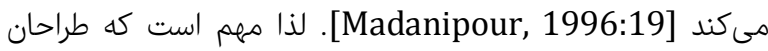

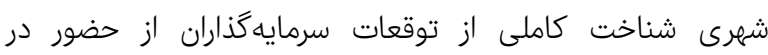
فضاىشهرى داشته باشند و نحوه تامين اين توقعات را نيز
ناظر در ارتباط با تناسبات، باز بودن، محصوريت و نفوذيذيرى توجه

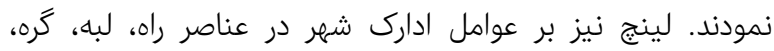

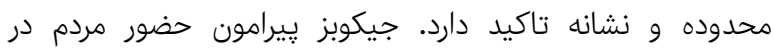

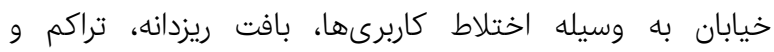

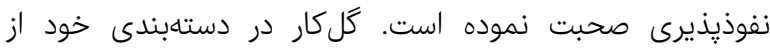
كيفيتهاى فضاى شهرى، كيفيتها را در قالب سه مولفه تجربى

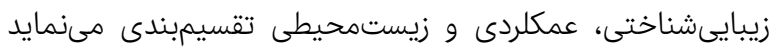

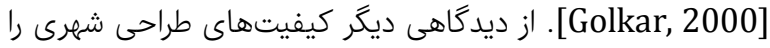

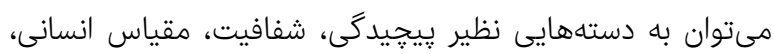

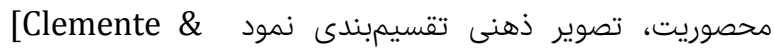

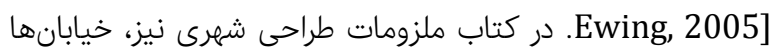
از جمله فضاهاى متعلق به قلمروى عمومى هستند كه بايد واجد

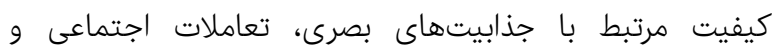

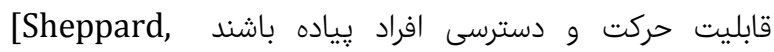

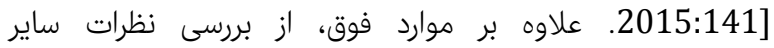

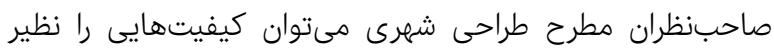

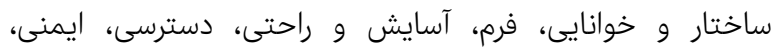

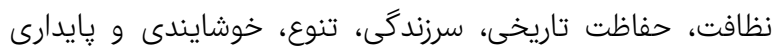

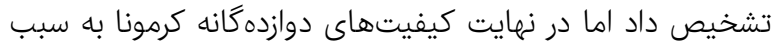

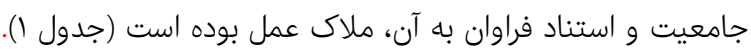

جدول (Carmona et al, 2008:15] كيفيتهاى عام فضاى شهرى

\begin{tabular}{|c|c|}
\hline تعريف & كيفيتهاى فضاى \\
\hline مراقبت و نظافت مناسب از فضاى شهرى & וاكيزگى تميزى و \\
\hline دسترسى و جابجايى راحت در فضاى شهرى & 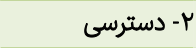 \\
\hline لطافت و حظ بصرى از فضاى شهرى & 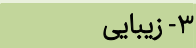 \\
\hline راحتى و امكان گذراندن اوقات در فضاى شهرى & ع- آسايش \\
\hline مطلوب و آزادبودن فضاى شهرى براى همه اقشار مردم & 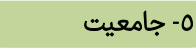 \\
\hline شهرى استفاده مطلوب و با نشاط اقشار مختلف مردم از فضاى & 7- سرزندگى \\
\hline تجمع مردم در فضاى شار شهرى فعاليتهاى مختلف و بدون فشار از & ل V - عملكردى بودن \\
\hline وجود شخصيت مثبت و قابل شناسايى از فضاى شهرى & 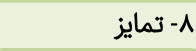 \\
\hline احساس ايمنى و سلامت در فضاى شهرى & 9- ايمنى و امنيت \\
\hline مقاومبودن فضاى شهرى در مقابل فشارهاى حاصل از & ما - استحكام \\
\hline شضور عناصر طبيعى و عدم آلودگى محيطى در فضاى & | - 11- سبز بودن \\
\hline حس رضايت نسبت به فضاى شهرى & 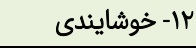 \\
\hline
\end{tabular}

در اين يزوهش با تكيه بر دستهبندى كرمونا كيفيتهاى فضاى

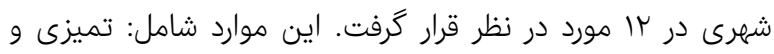

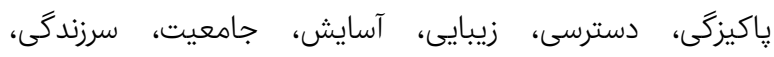

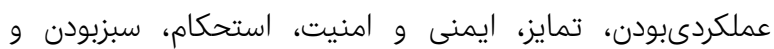

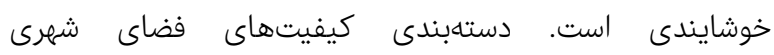




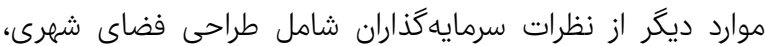

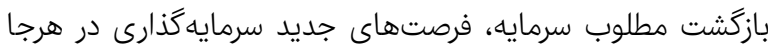

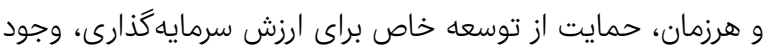
بازار مصرف مطمين، توجه به هزينه و دردسترسبودن سرايت سرمايه براى توسعه مى شود [Carmona \& Magalhaes, 2006:52]؛ البته انتظار سرمايهذاران از بازگشت سرمايه و رسيدن به سود بيشتر در

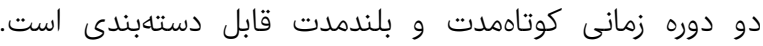

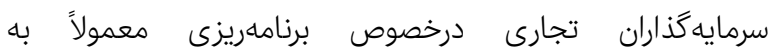

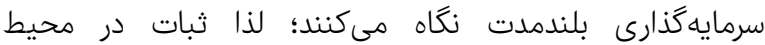

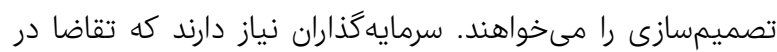
طول عمر يروزه وجود داشته باشد تا هزينه طراحى باعث كاهش

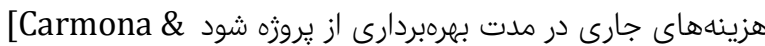
[Sieh, 2004:51] از طرف ديكر بايد توجه داشت كه كيفيت برديت

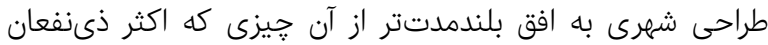

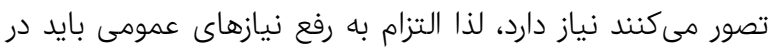

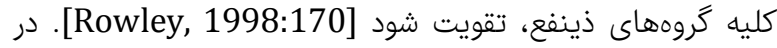

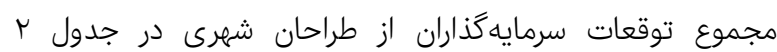

بخش عمدهاى از توجه بخش عمومى و شهردارىها در تحقق

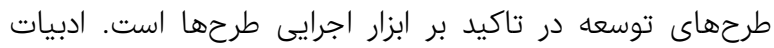

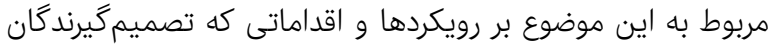

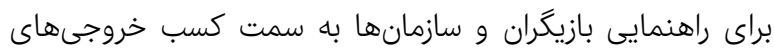

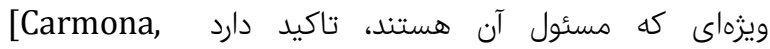

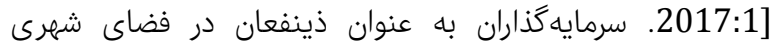

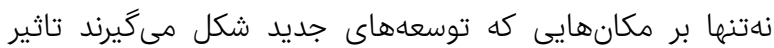

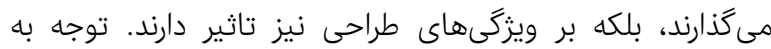

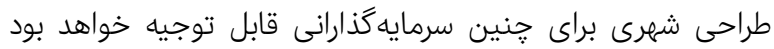

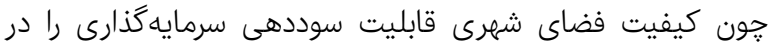
طول عمر يروزه به حداكثر خواهد رساند [Syms, 2002:240] لذا افزايش كيفيت فضاى شهرى تاثيرى خاص بر توقعات برات آنها

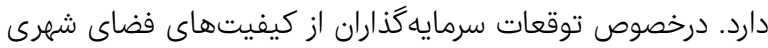

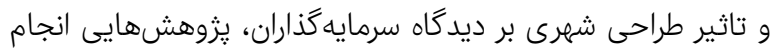

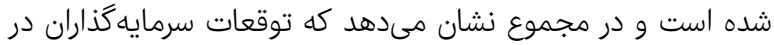

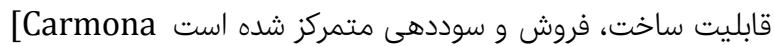

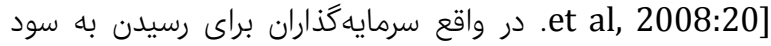

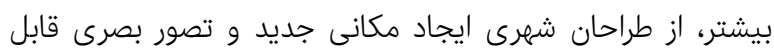

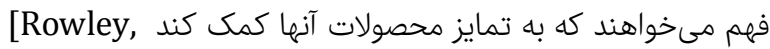

جدول r) توقعات سرمايهذاران از طراحان شهرى

\begin{tabular}{|c|c|c|}
\hline نظر سرمايهگذار در سود بلندمدت & نظر سرمايهگذار در سود كوتاهمدت & \\
\hline 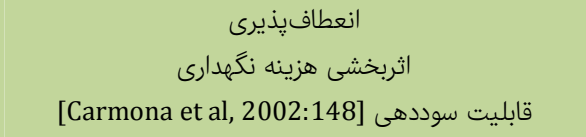 & 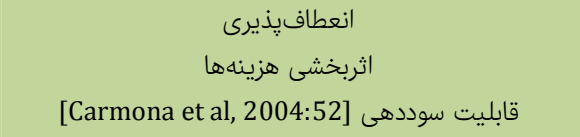 & ليه در استفاده از طراحى شهرى \\
\hline موافق - در صورت وجود بازار و طراحى شهرى با سود بيشتر & 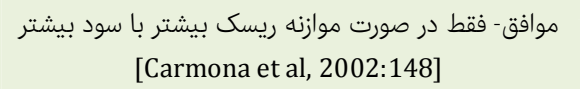 & جود طراحى شهرى \\
\hline 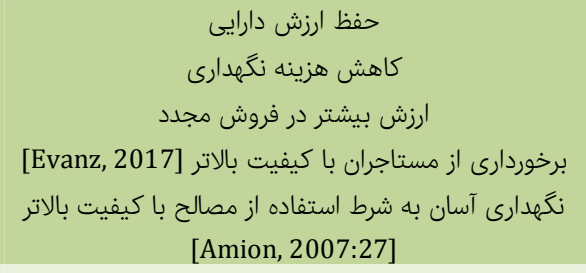 & 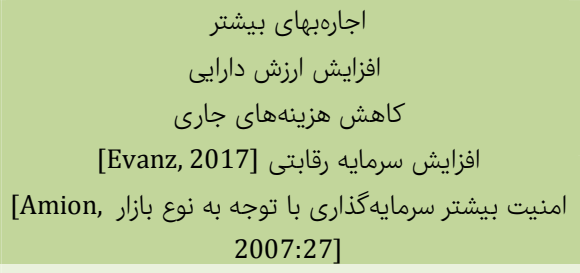 & وجود طراحى شهرى \\
\hline به حداكثر رسيدن سود & به حداكثر رسيدن سود & اهداف مالى در استفاده از طراحى شهرى \\
\hline موافق- به صورت وسيلهاى براى سود مالى & 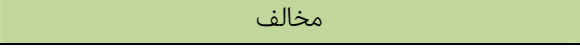 & طراحى شهرى براى حل مشكلات عملكردى \\
\hline
\end{tabular}

آن هميشه با حساسيت خاصى از سوى سرمايهگذاران بهمنظور

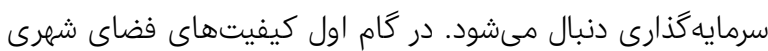

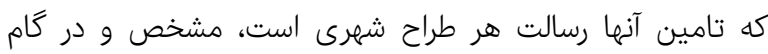

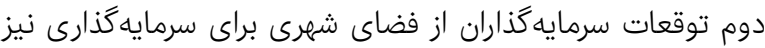

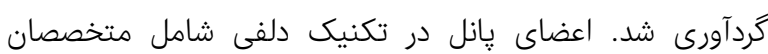
طراحان شهرى كه داراى سابقه و مهارت در طراحى و همجنين

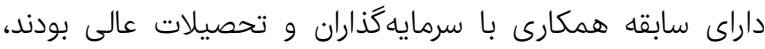

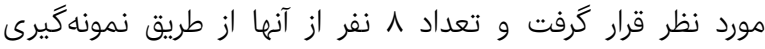
غيراحتمالى كلولهبرفى انتخاب شدند. با توجه به به تكنيك دلفى، إنى

\section{روش}

در اين يزوهش براساس روش توصيفى- تحليلى و با استفاده از

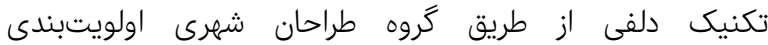
كيفيتهاى موثر در تامين توقعات سرمايهگذاران انجام شد. نمونه موردى اين يزوهش بافت مركزى شهر مشهد بود. شهر مشهر مهر

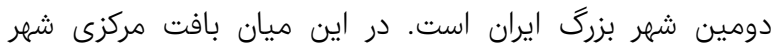

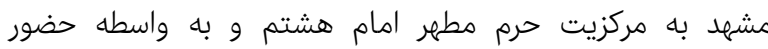

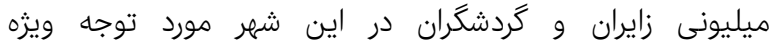
سرمايهگذاران داخلى و بينالملائى است و شرايط فضاهاى شهرى 
يافتهها

يس إز يايان دورهاى يرسشنامه نتايج حاصل در قالب جدول سّ و

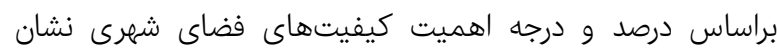

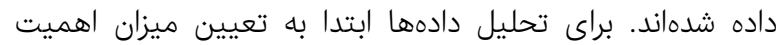

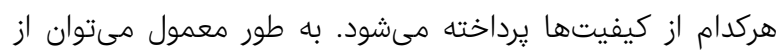

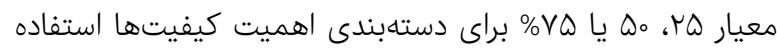

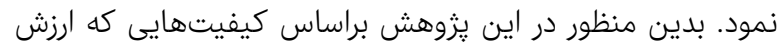

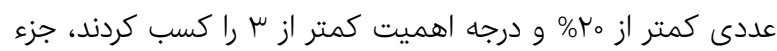

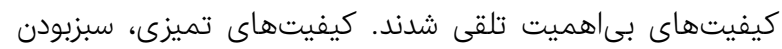

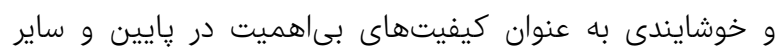
كيفيتها در محدوده مطلوب قرار كرفتنند.

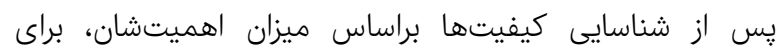

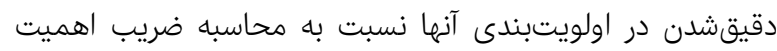

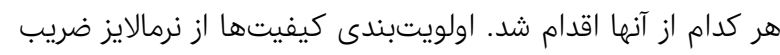

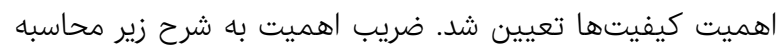

ضريب اهميت هر كيفيت يا معيار (IC) از حاصل ضرب درجه

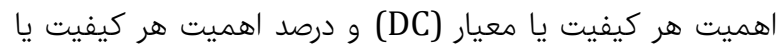
معيار (\%PC) محاسبه شد كه فرمول آن عبارت است ازيت

\section{$\mathrm{ICt}=\mathrm{DCt} \times(\% \mathrm{P}) \mathrm{Ci}$}

ضريب اهميت نرمالايزشده (OI) نيز از تقسيم ضريب اهميت هر يك از معيارها بر حاصلجمع ضريب اهميت معيارها محاسبه شد:

\section{$\mathrm{OICt}=\mathrm{ICt} \div \sum_{1}^{\mathrm{n}} \mathrm{ICi}$}

براساس جدول سّ، از ميان كيفيتهاى بررسىشده، كيفيت عملكردىبودن داراى بيشترين ضريب اهميت برديان بود كه به به عنوان بران

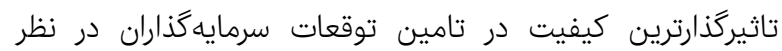

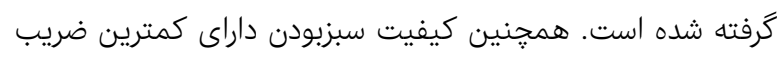
اهميت در تامين توقعات سرمايهذ كذاران شد.

يرسشناهه متخصصان تدوين و در آن تاثير كيفيتهاى فضاى

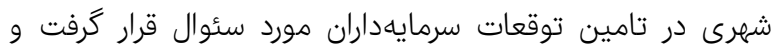

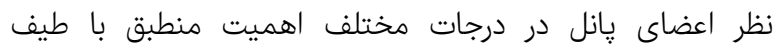
ينجمرحلهاى ليكرت ثبت شد.

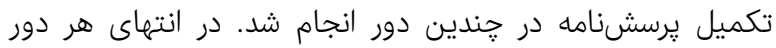

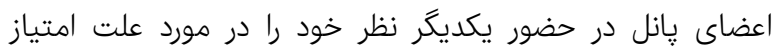

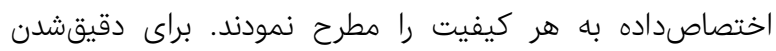

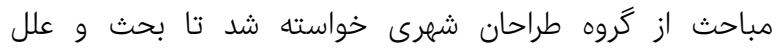

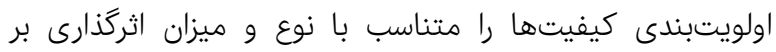

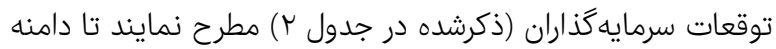
بحث مشخصتر شده و در جمعبندى نهايى نيز موثرتر باشد. براى

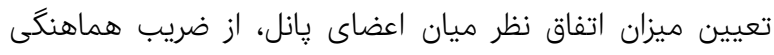

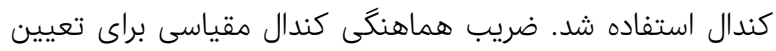

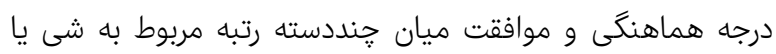

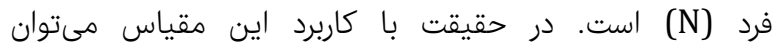

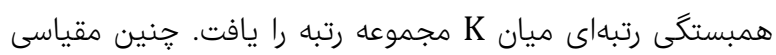

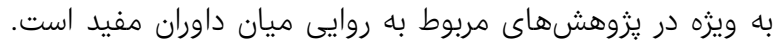

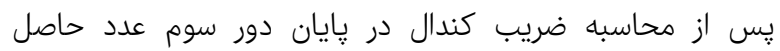

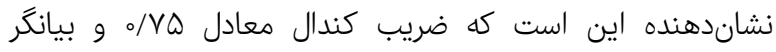

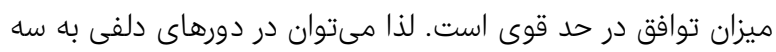

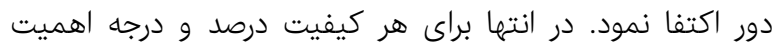

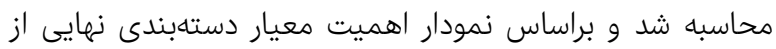

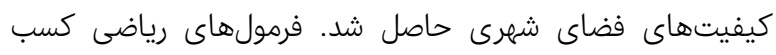

$\left(\mathrm{y}_{i}\right)=\frac{x t}{\Sigma x t}$

$\left(\mathrm{z}_{i}\right)=\mathrm{y}_{i} \times n$

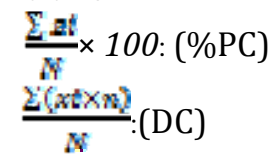

در فرمولهاى ذكرشده، N برابر با تعداد يرسششوندكان؛

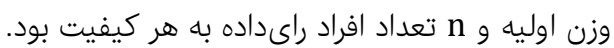

جدول س) ضرايب و اولويتبندى كيفيتهاى فضاى شهرى موثر در تامين توقعات سرمايهذاران

\begin{tabular}{|c|c|c|c|c|c|c|c|}
\hline كد حرفى & 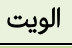 & ضريب اهميت نرمالايزشده (OI) & ضريب اهميت (IC) & درصد اهميت كيفيت & درجه اهميت كيفيت & كيفيت & رديف \\
\hline CL & 9 & $\Delta / \wedge$ & $\Delta Q / /$ & $19 / 1 V$ & $r / \Lambda \Lambda$ & تميزى و پِاكيزگى & 1 \\
\hline $\mathrm{AC}$ & $\mu$ & $11 / 1$ & $1.9 / 9 V$ & rG/GV & $k / 00$ & 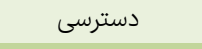 & r \\
\hline AT & $\Delta$ & $9 / \mathrm{V}$ & $q \mu / V Q$ & $r \Delta / \circ \circ$ & $\mu / V Q$ & 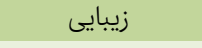 & $\mu$ \\
\hline CO & $\wedge$ & $\varepsilon / \mu$ & $9 \% \%$ & ro\% & $\mu / \circ$ & آسايش & F \\
\hline EX & r & $11 / 1$ & $\| \mathrm{H} / \mathrm{QV}$ & $r V / \omega_{\circ}$ & $k / N \mu$ & جامعيت & $\Delta$ \\
\hline VI & k & $10 / 0$ & $100 / r \mu$ & $r \Delta / \wedge \mu$ & $\mathrm{r} / \mathrm{\Lambda \Lambda}$ & سرزندگى & $\varepsilon$ \\
\hline FU & 1 & $10 / 8$ & $1 Q_{0} / k \mu$ & $M I / \varepsilon V$ & $K / V Q$ & عملكردىبودن & v \\
\hline DI & v & $V / \mathbb{R}$ & Vo/kr & $M Y / Q V$ & $\mu / \Gamma \Delta$ & 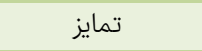 & $\wedge$ \\
\hline SA & $\varepsilon$ & $9 / 1$ & $\wedge \mathrm{V} / \mathrm{V} \mu$ & $M F / I V$ & $\mu / \varepsilon \mu$ & ايمنى و امنيت & 9 \\
\hline RO & 10 & $\Delta / \kappa$ & $Q_{0} / \mathbb{A}$ & $\mid N / \mu \mu$ & $r / V Q$ & استحكام & 10 \\
\hline GR & Ir & $r / V$ & rG/G६ & س س & r/oo & سبزبودن & 11 \\
\hline FU & 11 & $k / \Lambda$ & $k \& / . Y$ & $I V / \omega_{0}$ & $r / g \mu$ & خوشايندى & ir \\
\hline- & - & 100 & & q૬ा/॰V & & مجموع & \\
\hline
\end{tabular}


تامين توقعات اقتصادى سرمايهذذاران از طريق ايجاد برند و

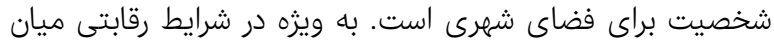

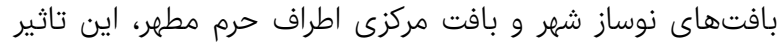

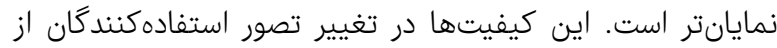
فضاى شعرى فرسوده به فضاى شعرى نو و كارآمد بسيار موثر

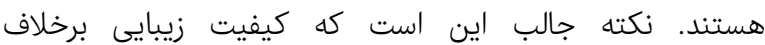

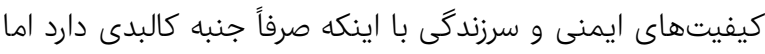

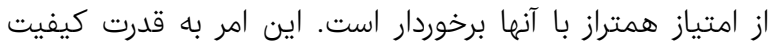

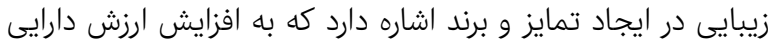

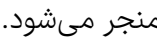
دسته سوم كيفيتهاى ضرورى يا اصلى هستند و اغلب در اكثر

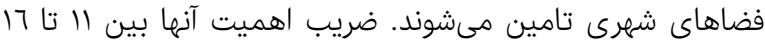

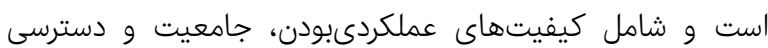
مىشوند. اين كيفيتها ملموس بوده و در حضور استفادهن كنندكان از فضاى شهرى نقش اساسى دارند. مهمترين تاثير آنها در تامين

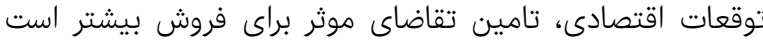

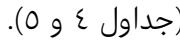

جدول F) دستهبندى كيفيتهاى طراحى شهرى براساس ميزان اثر آنها در

\begin{tabular}{|c|c|c|}
\hline اولويت & انواع كيفيتها & دسته \\
\hline اول تا سوم & عملكردىبودن، جامعيت، دسترسى & كيفيتهاى اصلى \\
\hline هشتهم تارم & سرزندگى، زيبايى، ايمنى و امنيت، تمايز، & كيفيتهاى \\
\hline دوازدهم تهم & تميزى، استحكام، خوشايندى، سبزبودن & كيفيتهاى فرعى \\
\hline
\end{tabular}

در بحث و بررسى يافتهها، به نحوه توزيع امتياز كيفيتها يرداخته

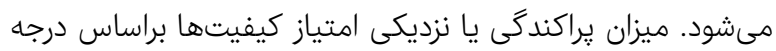

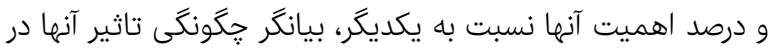

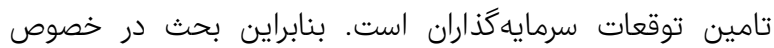

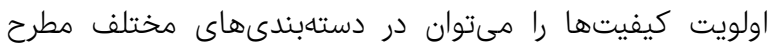

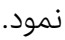

دسته اول كيفيتهايى هستند كه ضريب الويت آنها كمتر از شش

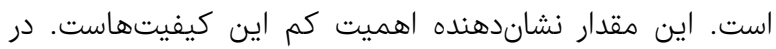

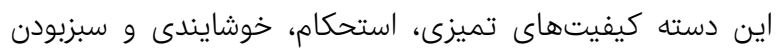
قرار دارد. علت تاثير كم اين كيفيتها، بيشتر در عامبودن آنها

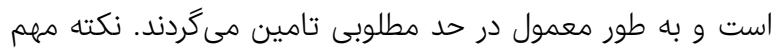

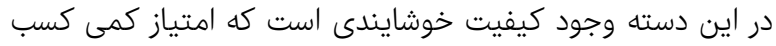

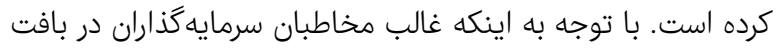

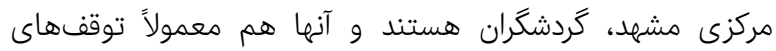
موقتى در شهر دارند، لذا وجود كيفيت خوشايندى ضرورتى ندارد.

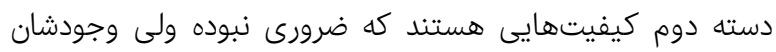
كمككننده به كيفيتهاى ضرورى است و و عاملى جذاب هاب براى

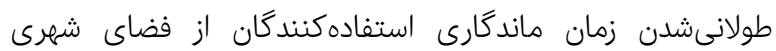
هستند؛ لذا اين دسته را مىتوان كيفيتهاى مكمل ناميد. ضريب

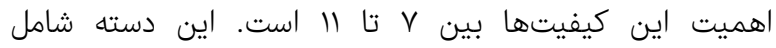

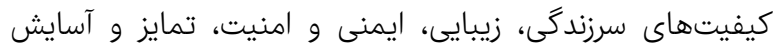

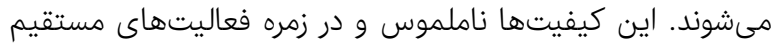

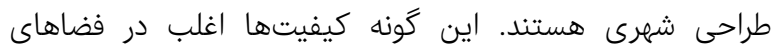
شهرى نادرى وجود دارند، لذا مهمترين تاثير اين كيفيتها در

جدول ه) ارتباط كيفيتهاى فضاى شهرى و توقعات سرمايهذار

\begin{tabular}{|c|c|c|c|c|c|}
\hline \multicolumn{3}{|c|}{ توقعات سرمايهذار } & \multicolumn{3}{|c|}{ اولويتبندى كيفيتهاى فضاى شهرى } \\
\hline توقعات توقعات درازمدت & ارفزايش قدرت رقابت بيشتر اجاره & توقعات بسيارموثر & كيفيتهاى اصلى & 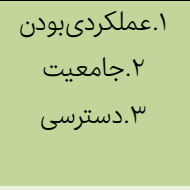 & اولويت اول تا سوم \\
\hline توقعات كيانمدت & حفظ ارزش اموال & توقعات نيماموثر & كيفيتهاى مكمل & 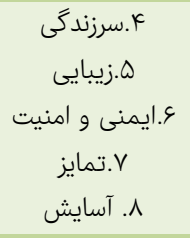 & اولويت جهارم تا هشتم \\
\hline توقعات كوتامهدت & قابليت سوددهى و كاهش & توقعات كمترموثر & كيفيتهاى فرعى & 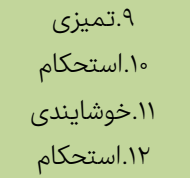 & اولويت نهم تا دوازدهم \\
\hline
\end{tabular}

رسيدن به سود بيشتر براى سرمايهگذاران است كه اين امر در دو نتيجه گيرى مقوله فروش بيشتر و افزايش قدرت رقابت، قابل خلاصهكردن در ارتباط با سئوال مطرحشده در اين يزوهش، نتايج حاصل از است. به عبارت ديگر براساس اصل عرضه و تقاضا، كيفيتهايى از

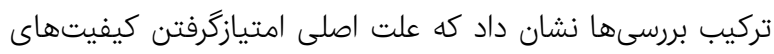

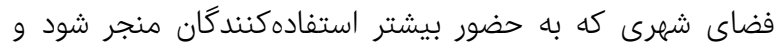

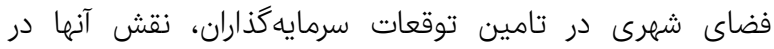


الويتبندى كيفيتهاى فضاى شهرى موثر در تامين توقعات سرمايهذاران؛ مطالعه موردى بافت مركزى شهر مشهد .

Design. 7(2):145-169.

- Carmona M, Sieh L (2004). Measuring quality in planning -Managing the performance process, London \& New York: Routledge Publication; pp. 51-52

- Carmona M, De Magalhaes C (2006). Innovations in the management of public space: Reshaping and refocusing governance. Planning Theory \& Practice. 7(3):52-61.

- Carmona M, De Magalhaes C, Hammond L (2008). Public space the management dimension. London: Routledge Publication. p. 20.

- Carmona M, Teasdale S (2015). Urban design reader, Zekavat K, Farshad F, Translators. Tehran: Azarakhs publication. p. 560. [Persian]

- Carmona M (2017). The formal and informal tools of design governance. Urban design. 22(1):1-36.

- Carr S, Francis M, Rivlin LG, Stone AM (1992). Public Space. Cambridge: Cambridge University Press. p. 230.

- Clemente 0, Ewing R (2005). Measuring urban design qualities an illustrated field manual, prepared for the Active Living Research Program of the Robert Wood Johnson Foundation. Maryland: University of Maryland, National Center for Smart Growth.

- Golkar K (2000). Urban design qualities. Sofe. 11(32):38-65. [Persian]

- Madanipour A (1997). Ambiguities of urban design. Liverpool University Press online. 63(3):363-375.

- Nase L, Berry J, Adair A (2015). Urban design quality and real state value. Urban Design. 20(5):563-581.

- Rowley A (1998), Private-property decision makers and the quality of urban design. Urban Design. 3(2):151172.

- Sadeghi S, sobhkhiz zenori Sh (2015). The effective factors on private sector cooperation as an approach to finance sustainable recourses of municipality projects. Urban Economics and Management. 3(11):153-167. [Persian]

- Sheppard M (2015). Essentials of urban design. CSIRO Publication. p. 312.

- Strenberg E (2000). An integrative theory of urban design. American Planning Association . 63(3):265-278.

- Syms P (2002). Land, Development and Design. Manchester: Willey-Blackwell Publication.

- Tibbalds, F (1992). Making people-friendly towns. First edition. London: Taylor and Francis Publication. p. 218.
باعث افزايش تقاضا شود، بيشتر مىتواند در تامين توقعات

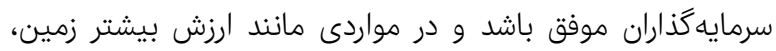

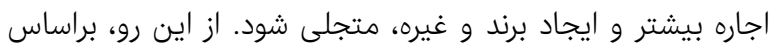

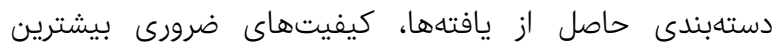
امتيازها را كسب نمودهاند. كيفيتهاى فوق زمينهساز انجام فعاليتهاى ضرورى در فضاى شهرى بوده و شروط اساسى حضور

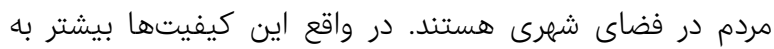

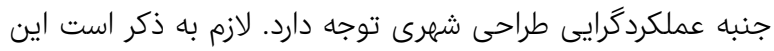
كيفيتها به توقعات موثر سرمايهگذاران در كوتاهمدات، ميانمدردات

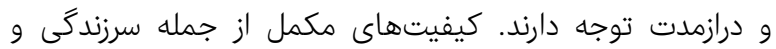
زيبايى به جنبه معنايى و هنرى طراحى شهرى اشاره دارد. تاثير دارئ

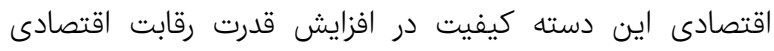

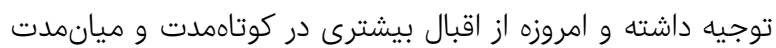

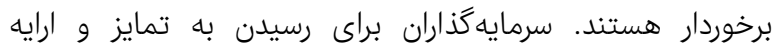

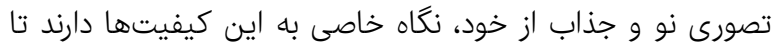

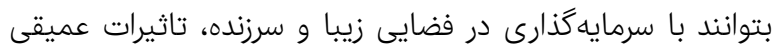
بر مخاطبان فضاى شهرى داشته باشند.

$$
\begin{aligned}
& \text { تشكر و قدردانى: موردى از سوى نويسندكان كزارش نشده است. }
\end{aligned}
$$

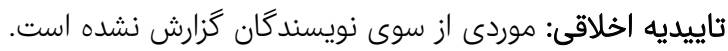

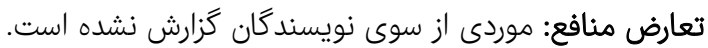

$$
\text { منابع مالى: موردى از سوى نويسندًان گزارش نشده است. }
$$

$$
\text { منابع }
$$

- Carmona M, De Magalhaes C, Edwards M (2002). Stakeholder views on value and urban design. Urban 